\title{
Photosynthetic Light Response of Floricane Leaves of Erect Blackberry Cultivars from Fruit Development into the Postharvest Period
}

\author{
Sydney Lykins, Katlynn Scammon, Brian T. Lawrence, \\ and Juan Carlos Melgar \\ Department of Plant and Environmental Sciences, Clemson University, 105 \\ Collings Street, 218 Biosystems Research Complex, Clemson, SC 29634
}

Additional index words. dark respiration, light compensation point, light saturation point, photosynthetic capacity, Rubus

\begin{abstract}
The photosynthetic light response of commercial blackberry cultivars (Rubus $\mathrm{L}$. subgenus Rubus Watson) is largely unexplored, although they are frequently grown in full sun. In this experiment, light response curves of floricane leaves from the cultivars Natchez, Apache, Navaho, and Von were examined throughout the following production stages: before shiny black fruit were present (before harvest, $\mathrm{BH}$ ), during peak production of fruit (peak harvest, $\mathrm{PH}$ ), and when most fruit had fallen from plants or any remaining were dull black (after harvest, $\mathbf{A H}$ ). Each cultivar was evaluated between an irradiance of 2000 and $0 \mu \mathrm{mol} \cdot \mathrm{m}^{-2} \cdot \mathrm{s}^{-1}$. The estimated maximum photosynthetic rate (photosynthetic capacity, $\boldsymbol{P}_{N \max }$ ) was greater BH than $\mathrm{AH}$ across all cultivars, whereas 'Natchez' had a greater $P_{N \max }$ BH and PH compared with the other cultivars. During AH, all cultivars had a similar $\boldsymbol{P}_{N \max }$. The BH response curves declined under the highest irradiance measured, whereas the $\mathrm{PH}$ and $\mathrm{AH}$ response curves remained stable at similarly high irradiance. Of the four cultivars, Apache, Navaho, and Von appeared to be more photosynthetically limited than Natchez under increasing irradiance. Based on the cultivar-specific performance observed, blackberry response to light is a relevant trait that breeding programs should consider for improving cultivar adaptability to local and regional conditions.
\end{abstract}

Blackberry (Rubus subgenus Rubus Watson) production has greatly increased since 2005 in North America, Central America, Australia, and Europe as a result of newly developed floricanefruiting and primocane-fruiting cultivars from both university and private breeding programs, development of marketing outlets, and an increase in fresh-market consumption (Clark and Finn, 2014; Hall, 2017). Numerous breeding efforts have improved fruit flavor, size, and shelf life, and there is a continued interest in improv-

Received for publication 12 Nov. 2020. Accepted for publication 21 Dec. 2020.

Published online 28 January 2021.

We thank the North American Raspberry and Blackberry Association for the financial support of the variety trial where this study occurred. We also thank Dave Ouellette and Sruthi Narayanan for reviewing this article, and the Musser Fruit Research Center staff and interns for their assistance maintaining the blackberry plants during the study.

This material is based on work supported by National Institute of Food and Agriculture/U.S. Department of Agriculture under project nos. SC-1700530 and SC-2017-04383, and is technical contribution no. 6887 of the Clemson University Experiment Station. S.L. is the corresponding author. E-mail: slykins@g. clemson.edu.

This is an open access article distributed under the CC BY-NC-ND license (https://creativecommons. org/licenses/by-nc-nd/4.0/). ing plant traits, such as a greater tolerance to cold temperatures during flowering and tolerance to intense sunlight (Clark and Finn, 2008; Takeda et al., 2013). With regard to light, Rubus spp. exhibit plasticity with respect to architecture and leaf physiology under different levels of irradiance (Gallagher et al., 2015). Field plantings are often designed to achieve maximum light interception depending on the latitude of production (Pritts and Hanson, 2017), although high irradiance combined with high temperature is known to lead to fruit sunscald, leaf burn, an increase in the incidence of white drupelet disorder (Finn and Clark, 2017; Takeda et al., 2013), and occasionally total plant collapse (Finn and Clark, 2011). Furthermore, the interception of light beyond the maximum capacity of the photosystems or photoprotective measures of the plant may induce oxidative stress before visible damage (Mullineaux and Karpinski, 2002). High irradiance is known to cause excess excitation energy in the light harvesting systems and reduce the efficiency of photosystem II (Barber, 1995; Powles, 1984). To counter light stress and prevent damage, plants use redox signaling and signal transduction pathways to elicit photoprotective measures and acclimate to persistent high light conditions (Foyer et al., 2017; Matsubara et al., 2016), but relatively little information exists on the performance of cultivated Rubus spp. under contrasting sunlight irradiance in warm subtropical growing regions.
Studies comparing blackberry production in full and partial sunlight show that plants receiving high irradiance have more concentrated flowering and harvest periods than plants with reduced irradiance (Gallagher et al., 2015; Rotundo et al., 1998). High tunnels are often used to extend the growing season for Rubus spp. in cooler climates, whereas plastic films can be formulated to buffer temperatures and alter the transmission of light to improve fruit yield and quality (Heidenreich et al., 2012; Strik et al., 2007). In warmer production regions, shade netting has recently been explored to reduce plant heat stress and possibly white drupelet disorder on blackberries (Caillouet, 2016; Spiers et al., 2014; Stafne et al., 2017). Similarly, rotating shift-arm trellises have shown to protect fruit from intense sunlight and high temperatures (Takeda et al., 2013). Despite several options to reduce or modify natural irradiance, the vast majority of production occurs without protective overhead structures such as high tunnels or shade nets (Strik et al., 2007).

Currently, a greater understanding of cultivar-specific responses to increasing irradiance is needed to avoid reduced photosynthetic capacity caused by high irradiance, and possibly warrant shade or tunnel structures for sun protection of some cultivars over others. Indeed, a comparison of several blackberry cultivars in South America concluded that the light compensation point and net photosynthesis varied between the four cultivars studied (Enciso and Gómez, 2004), but little is known about the photosynthetic performance of common commercial, fieldgrown blackberries and how they respond to irradiance during the growing season. We hypothesized that the plant photosynthetic response to light is cultivar specific and may also change with the stages of fruit development. Therefore, the objective of this work was to determine the photosynthetic capacity of four common commercial erect blackberries by comparing their responses to increasing irradiance.

\section{Materials and Methods}

Plant material and study design. The research was performed in a former variety trial of 5-year-old blackberry plants located at the Musser Fruit Research Center of Clemson University in Seneca, SC (lat. $34^{\circ} 36^{\prime} 22^{\prime \prime} \mathrm{N}$, long. $82^{\circ} 52^{\prime} 39^{\prime \prime} \mathrm{W}$ ), during 2019. Three plots consisting of five plants each of the erect blackberry cultivars Apache, Natchez, Navaho, and Von were used, being part of the variety trial with a randomized complete block design. Cultural management followed regional commercial practices: in-row white plastic mulch as orchard floor management, drip irrigation (each plant received $3.4 \mathrm{~L} \cdot \mathrm{h}^{-1}, 3 \mathrm{~h}$ per week), and fertigation with liquid calcium nitrate (applied once a week between April and July, and once a month in August and September) for an annual amount of nitrogen of 22.4 $\mathrm{kg} \cdot \mathrm{ha}^{-1}$. Fruit was not harvested at regular 
intervals during the season to maintain fruit on the measured plants.

Sampling periods, weather parameters, and light response curves. The photosynthetic light responses of the four cultivars were determined between the months of May and July during three sampling periods: 1) $\mathrm{BH}, 2$ ) during $\mathrm{PH}$, and 3 ) when nearly all or all fruit had naturally fallen from the plants (AH). The BH sampling period was determined by the time in which plants had only green or red developing fruit and few to no shiny black fruit present, the $\mathrm{PH}$ sampling period was designated by the weeks when many shiny black fruit were present and few developing fruit remained, and the $\mathrm{AH}$ sampling period was when plants had few dull black or no fruit remaining, with the majority of fruit removed by natural abscission. Weather and environmental parameters were monitored using a Davis Instruments Vantage Pro weather station (Davis Instruments, Hayward, CA). The daily maximum total solar irradiance along with the mean total solar irradiance at $0830 \mathrm{HR}$ and $1200 \mathrm{HR}$ were similar throughout the study period, with the highest and lowest levels recorded in June after a multiday rain event (Fig. 1). Daily precipitation was nearly absent during the last 2 weeks of May, but was more common in June and July. Mean daily humidity ranged between $61 \%$ to $77 \%$ in May, $53 \%$ to $96 \%$ in June, and $61 \%$ to $86 \%$ in July. Mean daily temperatures ranged from 23.9 to $27.6{ }^{\circ} \mathrm{C}$ in May, 20.2 to $27.5{ }^{\circ} \mathrm{C}$ in June, and 23.4 to $28.9^{\circ} \mathrm{C}$ in July. Light response curves were determined using a LICOR 6400-XTR portable photosynthesis system (LI-COR, Lincoln, NE) with an auxiliary LICOR 6400-02B lightemitting diode light source between $0830 \mathrm{HR}$ and $1200 \mathrm{HR}$. For each cultivar, measurements were taken from fully developed, east-facing floricane leaves on the third or fourth node of fruiting laterals 0.5 to $1.5 \mathrm{~m}$ off the ground. In the case of $\mathrm{AH}$ measurements, measurements were made on floricanes with visible pedicels after fruit abscission. Light response and gas exchange were measured for each photosynthetic photon flux density (PPFD) fraction of $200 \mu \mathrm{mol} \cdot \mathrm{m}^{-2} \cdot \mathrm{s}^{-1}$, starting from the highest irradiance at 2400 to $200 \mu \mathrm{mol} \cdot \mathrm{m}^{-2} \cdot \mathrm{s}^{-1}$, and then at 100,50 , and $0 \mu \mathrm{mol} \cdot \mathrm{m}^{-2} \cdot \mathrm{s}^{-1}$ (for a detailed plotting of the curve in the area near the compensation point) at 2-min average intervals (Evans and Santiago, 2014; Lobo et al., 2013). Light response curves for $\mathrm{BH}$ and $\mathrm{PH}$ were carried out using one leaf per plant and four plants per cultivar, whereas $\mathrm{AH}$ light response curves were constructed using one leaf per plant from only two plants per cultivar as a result of time constraints. Therefore, for each sampling period, the mean of four plants from the available 15 plants across the three plots were used to construct light response curves per cultivar during $\mathrm{BH}$ and $\mathrm{PH}$, whereas two plants were used during $\mathrm{AH}$. The same leaves were used for each set of measurements on a given day, measuring one cultivar or alternating between two cultivars for a total of four leaves each morning: 'Apache' (21 May; 22 May; 17 June; 2 July;
8 July), 'Natchez' (21 May; 22 May; 17 June; 2 July; 29 July), 'Navaho' (29 May; 4 June; 3 July; 9 July; 29 July), and 'Von' (28 May; 3 June; 3 July; 16 July; 30 July).

As a follow-up study to better understand the influence of fruit presence during $\mathrm{BH}$ on light response, the same methods were used to analyze both 'Natchez' and 'Apache' leaves the following season. However, 1 week before measuring light response, all developing fruit were removed from half of the plants, and the light response from four plants with and without fruit was compared for each cultivar.

Data and statistical analysis. Individual photosynthetic response curves were constructed using mean measurements per plant at each light level (SigmaPlot 13.0; Systat Software, San Jose, CA) using a modified rectangular hyperbola equation (Eq. [1]) described by Ye (2007), which resulted in the lowest sum of the squares of the errors among other equations commonly used to calculate light response curves as suggested by Lobo et al. (2013).

$$
\begin{aligned}
& P_{N}=\Phi_{\left(I o \_ \text {Icomp }\right)} \times[(1-\beta \times I) /(1+\gamma \times I)] \\
& \times\left(I-I_{\text {comp }}\right) \text {, }
\end{aligned}
$$

Variables in the equation include net $\mathrm{CO}_{2}$ assimilation $\left(P_{N}\right)$, the quantum yield $\left.\left[\Phi_{\left(I o \_I c o m p\right.}\right)\right]$ within the range of when irradiance equals zero and the light compensation point $\left(I_{\text {comp }}\right)$, the $P P F D$ or irradiance $(I)$, and several adjusting coefficients ( $\beta$ and $\gamma)$ inde- pendent of the irradiance (Ye, 2007). The $P_{N}$, $P_{\text {Nmax }}$, mitochondrial respiration rate $\left(R_{D}\right)$, light compensation point $\left(I_{\text {comp }}\right)$, and saturation irradiance $\left(I_{\max }\right)$ were calculated using Ye's (2007) equation model provided by Lobo et al. (2013). Comparisons of photosynthetic parameters by sampling period or cultivar were done using analysis of variance and Student's least significant difference mean separation tests using $\mathrm{JMP}^{\circledR}$ (version 14.1.0; SAS Institute, Cary, NC).

\section{Results and Discussion}

The photosynthetic light response of blackberry plants depended on the stage of fruit development and cultivar (Fig. 2, Table 1). Across all cultivars, the response curves of $\mathrm{BH}$ fruit had greater $P_{N \max }$ values $(P \leq 0.05)$ than AH. The response curves for $\mathrm{BH}$ showed declining $P_{N}$ values under increasing irradiance, with 'Navaho' reaching its $P_{\text {Nmax }}$ at the lowest irradiance among all cultivars $\left(661 \mu \mathrm{mol} \cdot \mathrm{m}^{-2} \cdot \mathrm{s}^{-1}\right)$, whereas $P_{N \max }$ started to decline near $1000 \mu \mathrm{mol} \cdot \mathrm{m}^{-2} \cdot \mathrm{s}^{-1}$ for 'Apache' and 'Von', and at $1125 \mu \mathrm{mol} \cdot \mathrm{m}^{-2} \cdot \mathrm{s}^{-1}$ for 'Natchez'. Among the cultivars studied, 'Natchez' had greater $P_{N \max }$ values than the other three cultivars $\mathrm{BH}$ and at $\mathrm{PH}$, whereas 'Navaho' had the lowest values; however, $P_{\text {Nmax }}$ was similar among all cultivars AH.

The $P_{N}$ values at $\mathrm{PH}$ or $\mathrm{AH}$ did not decline with increasing irradiance, with the exception of the PH curve of 'Natchez', which decreased slightly starting at an irradiance of more than $1600 \mu \mathrm{mol} \cdot \mathrm{m}^{-2} \cdot \mathrm{s}^{-1}$.

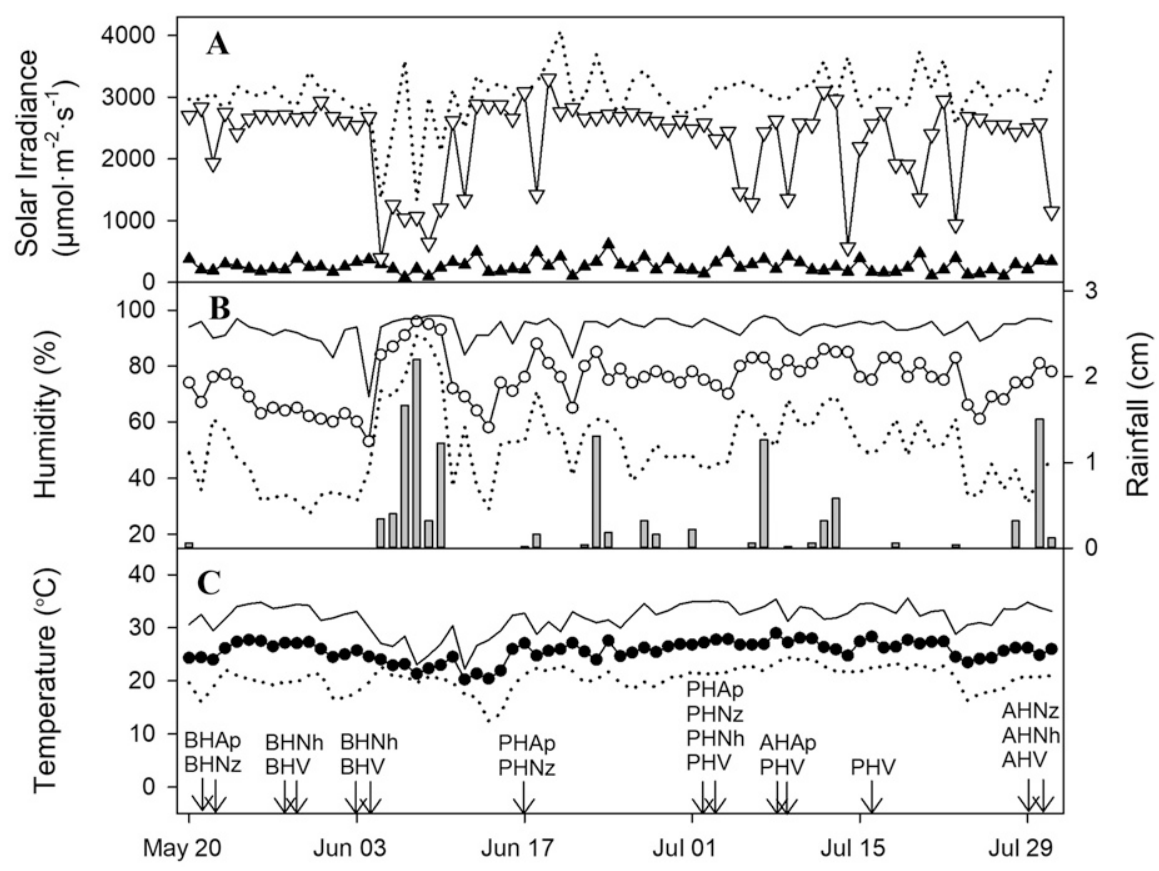

Fig. 1. Weather parameters during the 2019 growing season, including mean solar irradiance at $0830 \mathrm{HR}$ and $1200 \mathrm{HR}$ (filled and open triangles respectively), and the daily maximum (dotted line) (A); the daily maximum (solid line), minimum (dotted line), and mean humidity (open circles, \%), along with rainfall ( $\mathrm{cm}$, gray bars) (B); and the maximum (solid line), minimum (dotted line), and mean temperature (filled circles, ${ }^{\circ} \mathrm{C}$ ) during the study, along with arrows denoting sampling periods of before harvest $(\mathrm{BH})$, peak harvest $(\mathrm{PH})$, and after harvest $(\mathrm{AH})$ by cultivar: 'Apache' (Ap; 21 May; 22 May; 17 June; 2 July; 8 July), 'Natchez' (Nz; 21 May; 22 May; 17 June; 2 July; 29 July), 'Navaho' (Nh; 29 May; 4 June; 3 July; 9 July; 29 July), and 'Von' (V; 28 May; 3 June; 3 July; 16 July; 30 July) (C). 
Table 1. Photosynthetic parameters of four commercial blackberry cultivars (Apache, Natchez, Navaho, and Von) during three sampling periods (before harvest, peak harvest, and after harvest). Parameters include maximum photosynthesis $\left(P_{N \max }\right)$, dark respiration $\left(R_{D}\right)$, light compensation point $\left(I_{\text {comp }}\right)$, and light saturation point $\left(I_{\max }\right)$.

\begin{tabular}{llclll}
\hline & & \multicolumn{4}{c}{ Parameter $\left(\mu \mathrm{mol} \cdot \mathrm{m}^{-2} \cdot \mathrm{s}^{-1}\right)$} \\
\cline { 3 - 6 } Cultivar & Sample period & $P_{\text {Nmax }}$ & \multicolumn{1}{c}{$R_{D}$} & $I_{\text {comp }}$ & $I_{\max }$ \\
\hline Apache & Before & $12.2 \mathrm{~B}^{\mathrm{z}} \mathrm{a}^{\mathrm{y}}$ & $2.1 \mathrm{~A} \mathrm{a}$ & $33.1 \mathrm{~A} \mathrm{a}$ & $1005 \mathrm{AB} \mathrm{a}$ \\
& Peak & $9.2 \mathrm{~B} \mathrm{a}$ & $1.9 \mathrm{AB} \mathrm{a}$ & $35.6 \mathrm{~A} \mathrm{a}$ & $1194 \mathrm{~A} \mathrm{a}$ \\
\multirow{4}{*}{ Natchez } & After & $10.3 \mathrm{~A} \mathrm{a}$ & $1.9 \mathrm{~A} \mathrm{a}$ & $32.4 \mathrm{AB} \mathrm{a}$ & $1261 \mathrm{~A} \mathrm{a}$ \\
& Before & $15.2 \mathrm{~A} \mathrm{~b}$ & $2.1 \mathrm{~A} \mathrm{a}$ & $35.4 \mathrm{~A} \mathrm{~b}$ & $1125 \mathrm{~A} \mathrm{a}$ \\
& Peak & $18.1 \mathrm{~A} \mathrm{a}$ & $2.7 \mathrm{~A} \mathrm{a}$ & $45.3 \mathrm{~A} \mathrm{~b}$ & $1345 \mathrm{~A} \mathrm{a}$ \\
\multirow{3}{*}{ Navaho } & After & $9.9 \mathrm{~A} \mathrm{c}$ & $2.2 \mathrm{~A} \mathrm{a}$ & $63.5 \mathrm{~A} \mathrm{a}$ & $1613 \mathrm{~A} \mathrm{a}$ \\
& Before & $8.7 \mathrm{C} \mathrm{a}$ & $1.3 \mathrm{~B} \mathrm{a}$ & $18.6 \mathrm{~B} \mathrm{~b}$ & $661 \mathrm{~B} \mathrm{~b}$ \\
& Peak & $9.6 \mathrm{~B} \mathrm{a}$ & $1.1 \mathrm{AB} \mathrm{a}$ & $15.9 \mathrm{~A} \mathrm{~b}$ & $1040 \mathrm{~A} \mathrm{a}$ \\
& After & $6.8 \mathrm{~A} \mathrm{a}$ & $1.1 \mathrm{~A} \mathrm{a}$ & $31.8 \mathrm{AB} \mathrm{a}$ & $1076 \mathrm{AB}$ a \\
& Before & $11.3 \mathrm{BC} \mathrm{a}$ & $0.4 \mathrm{~B} \mathrm{~b}$ & $15.4 \mathrm{~B} \mathrm{a}$ & $998 \mathrm{~A} \mathrm{ab}$ \\
& Peak & $9.4 \mathrm{~B} \mathrm{~b}$ & $0.9 \mathrm{~B} \mathrm{ab}$ & $17.9 \mathrm{~A} \mathrm{a}$ & $1216 \mathrm{~A} \mathrm{a}$ \\
& After & $7.5 \mathrm{~A} \mathrm{~b}$ & $1.5 \mathrm{~A} \mathrm{a}$ & $20.2 \mathrm{~B} \mathrm{a}$ & $774 \mathrm{~B} \mathrm{~b}$ \\
\hline
\end{tabular}

${ }^{\mathrm{z}}$ Uppercase letters show significant differences between cultivars by sampling period according to Student's least significant difference (LSD) mean separation tests $(\alpha=0.05)$.

${ }^{\mathrm{y}}$ Lowercase letters show significant differences between sample periods by cultivar according to Student's LSD mean separation tests $(\alpha=0.05)$.

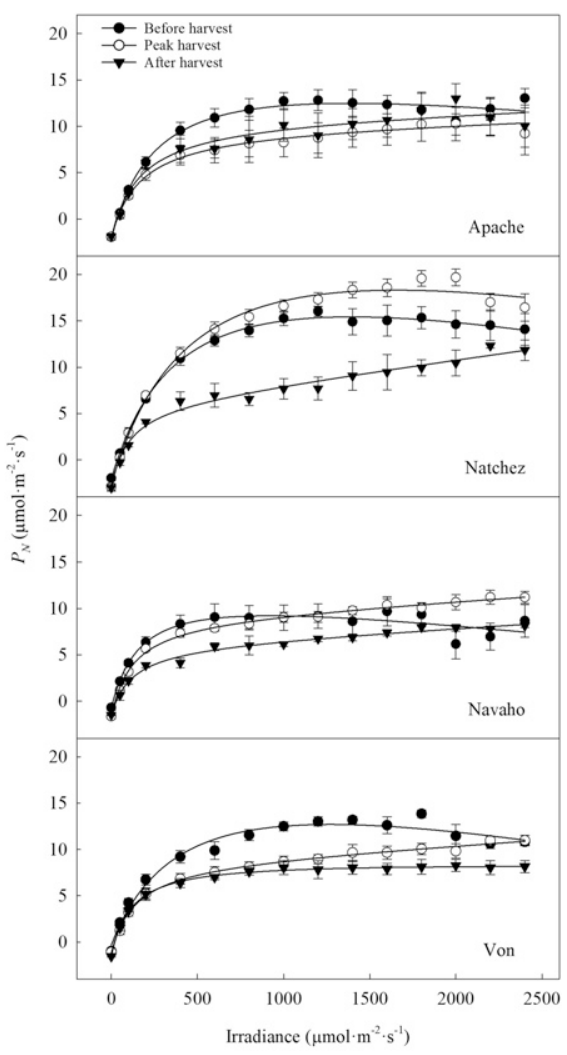

Fig. 2. Mean $\mathrm{CO}_{2}$ assimilation $\left(P_{N}, \mu \mathrm{mol} \cdot \mathrm{m}^{-2} \cdot \mathrm{s}^{-1}\right)$ by increasing irradiance (photosynthetic photon flux density, $\left.\mu \mathrm{mol} \cdot \mathrm{m}^{-2} \cdot \mathrm{s}^{-1}\right)$ of four commercial blackberry cultivars (Apache, Natchez, Navaho, and Von) during before harvest (solid circles), peak harvest (open circles), and after harvest (solid triangles) sampling periods. Error bars represent \pm SE (before and peak harvest, $\mathrm{n}=4$; after harvest, $\mathrm{n}=2$ ).

Regarding $P_{\text {Nmax }}$, 'Natchez' had notably greater values $\mathrm{BH}(P \leq 0.01)$ and $\mathrm{PH}(P \leq$ $0.001)$, but not AH $(P>0.05)$ in comparison with the other three cultivars. When comparing sampling periods by cultivar, 'Natchez' was estimated to have a greater $(P \leq 0.001)$ $P_{\text {Nmax }} \mathrm{BH}$ and at $\mathrm{PH}$ than $\mathrm{AH}$. 'Von' was sponse curves may be specific to cultivar, similar to the results reported by Enciso and Gómez (2004) on four Colombian blackberry cultivars.

'Natchez' had greater $R_{D}$ values in comparison with the other three cultivars analyzed across sampling periods $(P \leq 0.01$; Table 1). By cultivar, $R_{D}$ values were similar among sampling periods except for 'Von', which showed lower $R_{D}(P \leq 0.05) \mathrm{BH}$ than $\mathrm{AH}$. The acclimation of $R_{D}$ to available light has been explored in forest species (Lusk and Reich, 2000) and generally decreases with more shaded environments. Because all cultivars were grown in the field under similar irradiance, the greater $R_{D}$ values of 'Apache' and 'Natchez' BH in comparison with ' $\mathrm{Na}$ vaho' and 'Von' is perhaps a reflection of larger fruit size or yield, as all cultivars had similar $R_{D}$ values $\mathrm{AH}$. Nonetheless, the brief study that occurred the following growing season examining both 'Apache' and 'Natchez' plants with and without fruit showed no differences in $R_{D}, I_{c o m p}$, or $I_{\max } \mathrm{BH}$ (data not shown). Yield among the four cultivars had been calculated the previous 3 years and revealed all four cultivars had similar yield, with the exception of 'Apache' the final year of the variety trial (Lawrence et al., 2020); however, no yield data were collected for this study. Therefore, it is possible differences in fruit yield among the four cultivars may have resulted in different $R_{D}$ values as well.

Across sampling periods, 'Natchez' had the greatest $I_{\text {comp }}(P \leq 0.001)$ values in comparison with the other three cultivars (Table 1). The $I_{\text {comp }}$ values for 'Natchez' and 'Navaho' BH and PH were both less ( $P \leq$ $0.05)$ than AH, whereas 'Apache' and 'Von' had similar $I_{\text {comp }}$ values for all three sampling periods. The $I_{\text {comp }}$ values for each of our cultivars were similar to previous reports of 'Illini Hardy' blackberries, which-under $100 \%$ irradiance - had an $I_{\text {comp }}$ value of 40 $\mu \mathrm{mol} \cdot \mathrm{m}^{-2} \cdot \mathrm{s}^{-1}$ (Gallagher et al., 2015). Only 'Natchez' and 'Navaho' appeared to have an increase in $I_{\text {comp }}$ after fruit removal. Although a decrease of $I_{\max }$ has been observed in apple leaves after fruit removal, $I_{\text {comp }}$ is not always affected by the presence of fruit (Tartachnyk and Blanke, 2004). Because the increase in $I_{\text {comp }}$ for 'Natchez' and 'Navaho' AH was not the result of an increase in $R_{D}$, it is possibly an artifact of older leaves being analyzed.

The $I_{\max }$ value of 'Navaho' BH was less than that at $\mathrm{PH}$ or $\mathrm{AH}(P \leq 0.01)$, whereas 'Von' had a lower $I_{\max }$ value AH compared with PH $(P \leq 0.05$; Table 1$)$. 'Apache' and 'Natchez' showed numerically increasing $I_{\max }$ values from $\mathrm{BH}$ throughout $\mathrm{AH}$, although differences were not significant. Light saturation of blackberries has been previously reported to occur at 750 to 900 $\mu \mathrm{mol} \cdot \mathrm{m}^{-2} \cdot \mathrm{s}^{-1}$ (Caillouet, 2016), which could be between one third to one fourth the maximum daily irradiance of most blackberry growing regions, depending on latitude (about a third of the maximum irradiance at our location; Fig. 1). Light saturation in this study appeared to be generally greater than the 


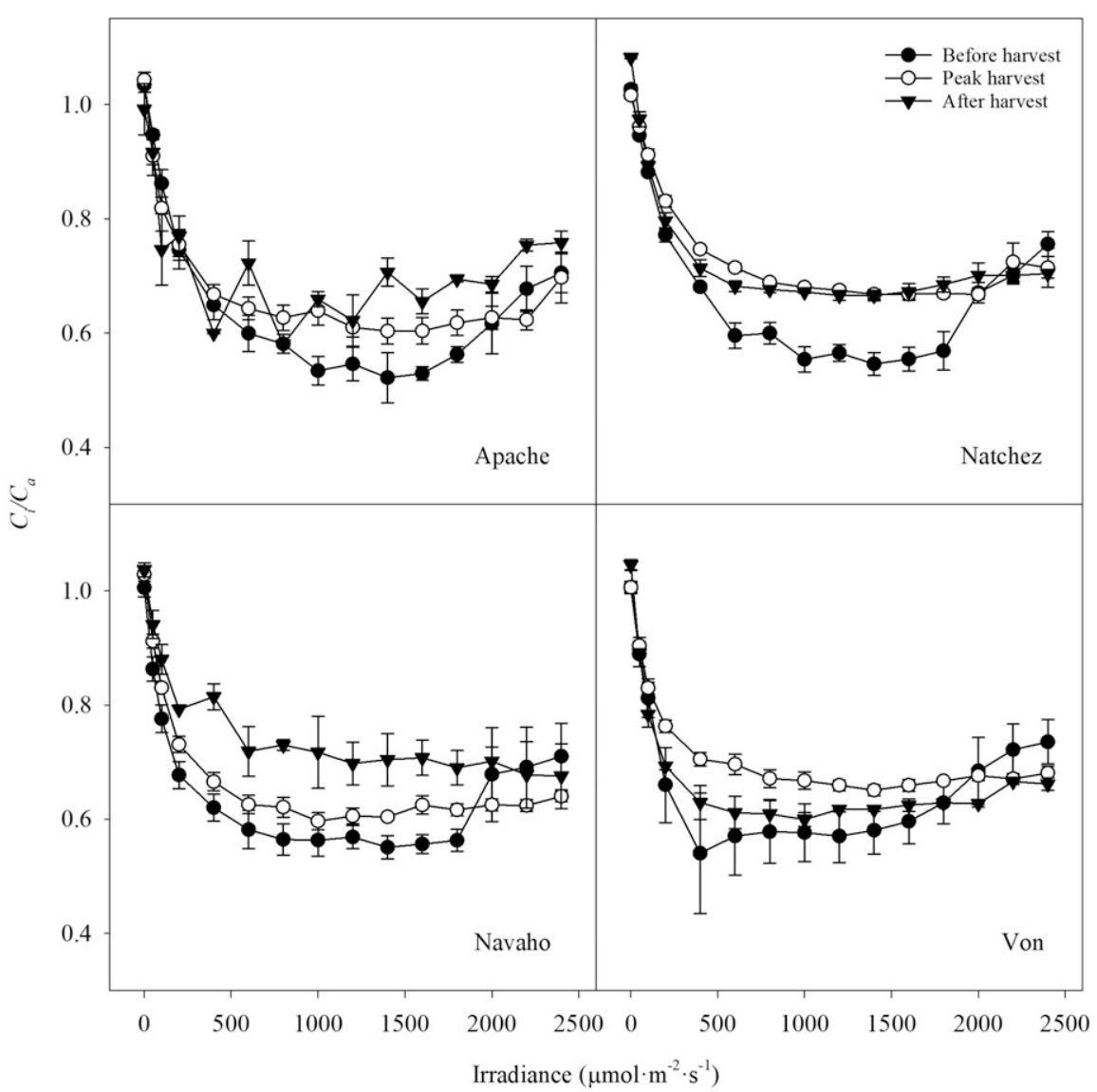

Fig. 3. Mean ratio of mesophyll $\mathrm{CO}_{2}$ concentration to atmospheric $\mathrm{CO}_{2}$ concentration $\left(C_{i} / C_{a}\right)$ by increasing irradiance (photosynthetic photon flux density, $\mu \mathrm{mol} \cdot \mathrm{m}^{-2} \cdot \mathrm{s}^{-1}$ ) of four commercial blackberry cultivars (Apache, Natchez, Navaho, and Von) during before harvest (solid circles), peak harvest (open circles), and after harvest (solid triangles) sampling periods. Error bars represent \pm SE (before and peak harvest, $\mathrm{n}=4$; after harvest, $\mathrm{n}=2$ ).

values reported by Caillouet (2016), and several cultivars, including Apache and Natchez, had estimates of $I_{\max }$ greater than 1000 $\mu \mathrm{mol} \cdot \mathrm{m}^{-2} \cdot \mathrm{s}^{-1}$ for each sample period.

The $C_{i} / C_{a}$ of the $\mathrm{BH}$ sampling period showed increasing values for all cultivars when receiving irradiance greater than 1600 to $1800 \mu \mathrm{mol} \cdot \mathrm{m}^{-2} \cdot \mathrm{s}^{-1} \mathrm{BH}$ (Fig. 3). The PH and $\mathrm{AH}$ sampling periods, however, showed more consistent $C_{i} / C_{a}$ values during increasing irradiance (with the exception of $\mathrm{PH}$ and $\mathrm{AH}$ 'Apache', and $\mathrm{AH}$ 'Von'). The mean $C_{i}$ $/ C_{a}$ between the irradiance values of 600 and $1600 \mu \mathrm{mol} \cdot \mathrm{m}^{-2} \cdot \mathrm{s}^{-1}$ revealed that all cultivars were similar during the $\mathrm{BH}$ period $(P>0.05)$, 'Apache' and 'Navaho' had a lower $C_{i} / C_{a}$ value than 'Natchez' and 'Von' $\mathrm{PH}(P \leq$ $0.001)$, and 'Von' had lower values than 'Apache', 'Natchez', and 'Navaho' AH ( $P$ $\leq 0.001)$. Similar analysis of stomatal conductance across the same values showed that 'Natchez' had greater conductance than other cultivars $\mathrm{BH}$ and at $\mathrm{PH}$ (data not shown).

To our knowledge, we present the first information regarding $C_{i} / C_{a}$ curves by different irradiance for commercial blackberry cultivars. Studying how $C_{i} / C_{a}$ is influenced by irradiance can provide responses indirectly on the performance of Rubisco (increasing $C_{i} / C_{a}$ values may correspond with trellis structures. The use of reflective mulches, high tunnels, and shade structures in warmer climates (Caillouet, 2016; Makus, 2010; Rotundo et al., 1998) has been suggested to alter irradiance and reduce temperature, but some of these strategies may not be appropriate for all growers, depending on latitude or orchard orientation.

This study demonstrates there are cultivarspecific differences that may affect blackberry performance in the field. Specifically, the four commercial blackberry cultivars studied had different responses to increasing irradiance. 'Natchez', which had greater BH and PH $P_{\text {Nmax }}$ values, may perform best in regions that receive greater irradiance, whereas cultivars such as 'Navaho', which had lower $P_{\text {Nmax }}$ values throughout the sample periods, may adapt better to areas with lower irradiance. Provided the demand of fresh-market blackberry fruit continues, evaluations of cultivars by photosynthetic performance in warmer climates could assist breeders or growers when making selections for heat- or lighttolerant genotypes, depending on climatic field conditions.

\section{Literature Cited}

Barber, J. 1995. Molecular basis of the vulnerability of photosystem II to damage by light. Aust. J. Plant Physiol. 22:201-208, doi: 10.1071/ PP9950201.

Caillouet, O.C. 2016. The effects of shade on growth, development and yield of a primocane fruiting blackberry, 'Prime Ark 45 ' to extend the market season. Univ. of Arkansas, Fayetteville, undergraduate thesis.

Cameron, J.S., S.F. Kaluer, and C. Chen. 1993. Development and environmental influences on the photosynthetic biology of red raspberry (Rubus idaeus L.). Acta Hort. 352:113-120, doi: 10.17660/ActaHortic.1993.352.15.

Clark, J.R. and C.E. Finn. 2008. New trends in blackberry breeding. Acta Hort. 777:41-48, doi: 10.17660/ActaHortic.2008.777.2.

Clark, J.R. and C.E. Finn. 2014. Blackberry cultivation in the world. Rev. Bras. Frutic. 36(1):46-57, doi: 10.1590/0100-2945-445/13.

Clark, J.R. and J.N. Moore. 2008. 'Natchez' thornless blackberry. HortScience 43:1897-1899, doi: 10.21273/HORTSCI.43.6.1897.

Enciso, B.E. and C. Gómez. 2004. Comparación de las respuestas de cuatro cultivares de mora. Agron. Colomb. 22(1):46-52.

Evans, J.R. and L.S. Santiago. 2014. PrometheusWiki gold leaf protocol: Gas exchange using LI-COR 6400. Funct. Plant Biol. 41:223-226, doi: 10.1071/FP10900.

Fernandez, G. and M. Pritts. 1994. Growth, carbon acquisition, and source-sink relationships in 'Titan' red raspberry. HortScience 29:248b248, doi: 10.21273/HORTSCI.29.4.248b.

Finn, C.E. and J.R. Clark. 2011. Blackberry, p. 6392. In: M.L. Badenes and D.H. Byrne (eds.). Fruit breeding. Springer, New York, NY.

Finn, C.E. and J.R. Clark. 2017. Cultivar development and selection, p. 63-82. In: H.K. Hall and R.C. Funt (eds.). Blackberries and their hybrids: Crop production science in horticulture. CABI, Boston, MA.

Foyer, C.H., A.V. Ruban, and G. Noctor. 2017. Viewing oxidative stress through the lens of oxidative signaling rather than damage. Biochem. J. 474(6):877-883, doi: 10.1042/BCJ20160814. 
Gallagher, E.J., K.W. Mudge, M.P. Pritts, and S.D. DeGloria. 2015. Growth and development of 'Illini Hardy' blackberry (Rubus subgenus Eubatus Focke) under shaded systems. Agrofor. Syst. 89(1):1-17, doi: 10.1007/s10457-014-9738-x.

Hall, H.K. 2017. World blackberry production, p. 308-314. In: H.K. Hall and R.C. Funt (eds.). Blackberries and their hybrids: Crop production science in horticulture. CABI, Boston, MA.

Heidenreich, C., M. Pritts, K. Demchak, E. Hanson, C. Weber, and M.J. Kelly. 2012. High tunnel raspberries and blackberries. Cornell Univ. Dept. Hort. Publ. 47.

Lawrence, B.T., J.C. Melgar, M.J. Dallmann, D.R. Ouellette, M. Hu, and G. Schnabel. 2020. Field performance and susceptibility to fungal pathogens of eleven blackberry cultivars. Intl. J. Fruit Sci. 20:605-616, doi: 10.1080/15538362. 2020.1749922.

Lobo, F.D.A., M.P. De Barros, H.J. Dalmagro, Â.C. Dalmolin, W.E. Pereira, E.C. De Souza, and C.R. Ortíz. 2013. Fitting net photosynthetic lightresponse curves with Microsoft Excel: A critical look at the models. Photosynthetica 51(3):445456, doi: 10.1007/s11099-013-0045-y.

Lusk, C.H. and P.B. Reich. 2000. Relationships of leaf dark respiration with light environment and tissue nitrogen content in juveniles of 11 cold-temperate tree species. Oecologia 123:318 329, doi: $10.1007 / \mathrm{s} 004420051018$.

Makus, D.J. 2010. Weed control and canopy light management in blackberries. Intl. J. Fruit Sci. 10(2):177186, doi: 10.1080/15538362.2010.492335.

Matsubara, S., T. Schneider, and V.G. Maurino. 2016. Dissecting long-term adjustments of photoprotective and photo-oxidative stress acclimation occurring in dynamic light environments. Front. Plant Sci. 7:1690, doi: 10.3389/ fpls.2016.01690.

Mullineaux, P. and S. Karpinski. 2002. Signal transduction in response to excess light: Getting out of the chloroplast. Curr. Opin. Plant Biol. 5(1):4348, doi: 10.1016/S1369-5266(01)00226-6.

Naschitz, S., A. Naor, S. Wolf, and E.E. Goldschmidt. 2014. The effects of temperature and drought on autumnal senescence and leaf shed in apple under warm, east Mediterranean climate. Trees 28(3):879-890, doi: 10.1007/ s00468-014-1001-6.

Powles, S.B. 1984. Photoinhibition of photosynthesis induced by visible light. Annu. Rev. Plant Physiol. 35:15-44, doi: 10.1146/annurev.pp.35.060184.000311.

Pritts, M. and E. Hanson. 2017. Site preparation, soil management, and planting, p. 118-130. In: H.K. Hall and R.C. Funt (eds.). Blackberries and their hybrids: Crop production science in horticulture. CABI, Boston, MA.

Rotundo, A., M. Forlani, and C. Di Vaio. 1998. Influence of shading net on vegetative and productive characteristics, gas exchange, and chlorophyll content of the leaves in two blackberry (Rubus ulmifolius Schott.) cultivars. Acta Hort. 457:333-340, doi: 10.17660/ActaHortic. 1998.457.42.

Spiers, J.D., J.A. Pitts, R.T. Boozer, and J.R. Clark. 2014. Influence of high tunnel and shade on blackberry yield and white drupelet disorder. HortScience 49:S405.

Stafne, E.T., J.R. Clark, and C.R. Rom. 2001. Leaf gas exchange response of 'Arapaho' blackberry and six red raspberry cultivars to moderate and high temperatures. HortScience 36:880-883, doi: 10.21273/HORTSCI.36.5.880.

Stafne, E.T., A. Rezazadeh, M. Miller-Butler, and B.J. Smith. 2017. Environment affects white drupelet disorder expression on three blackberry cultivars in south Mississippi. HortTechnology 27:840-845, doi: 10.21273/ HORTTECH03880-17.

Stanton, M.A., J.C. Scheerens, R.C. Funt, and J.R. Clark. 2007. Floral competence of primocanefruiting blackberries Prime-Jan and PrimeJim grown at three temperature regimens. HortScience 42:508-513, doi: 10.21273/HORTSCI 42.3.508.

Strik, B.C., J.R. Clark, C.E. Finn, and M.P. Bañados. 2007. Worldwide blackberry production. HortTechnology 17:205-213, doi: 10.21273/HORTTECH.17.2.205.

Takeda, F., D.M. Glenn, and T. Tworkoski. 2013. Rotating cross-arm trellis technology for blackberry production. J. Berry Res. 3:25-40, doi: 10.3233/JBR-130044.

Tartachnyk, I.I. and M.M. Blanke. 2004. Effect of delayed fruit harvest on photosynthesis, transpiration and nutrient remobilization of apple leaves. New Phytol. 164(3):441-450, doi: 10.1111/j.1469-8137.2004.01197.x.

Ye, Z.P. 2007. A new model for relationship between irradiance and the rate of photosynthesis in Oryza sativa. Photosynthetica 45(4):637-640, doi: 10.1007/s11099-007-0110-5. 